\title{
Examining the Role of BATNA in Explaining EPA Negotiation Outcomes
}

James Nyomakwa-Obimpeh

University of Cologne, Cologne, Germany

\begin{abstract}
The European Union has been negotiating regional Economic Partnership Agreements (EPAs) with 79 African, Caribbean and Pacific (ACP) Group of States since 2002 with different outcomes. For instance, while the negotiation with the Caribbean Forum concluded as envisaged in 2007, those with the Economic Community of West African States and other ACP countries have extended for nearly a decade after the initial deadline. This study discusses the rationale behind these different outcomes. The study concludes that for the European Union to have effective trade negotiations with the ACP countries, it needs to look beyond its market size attraction and policy to promote the idea of free trade. Moreover, it should analyse alternative trade options available to those regions and develop appropriate negotiation positions and strategies.
\end{abstract}

JEL Classifications: F02, F13, F14, F15, F51, F68

Keywords: Economic Partnership Agreement, Trade Negotiation Outcomes, Best Alternative To the Negotiated Agreement (BATNA), ACP Group of States, European Union, ECOWAS, CARIFORUM

\footnotetext{
* Corresponding author: James Nyomakwa-Obimpeh; University of Cologne, Jean Monnet Chair of Political Science and European Affairs, Gottfried-Keller-Strasse 6, 50931 Cologne, Germany \& University of Edinburgh, School of Social and Political Science, Politics and International Relations, Chrystal Macmillan Building, 15a George Square, EH8 9LD, Edinburgh, United Kingdom, Tel: +49221470 8617, Fax:+492214701492, Email: j.nyomakwa-obimpeh@uni-koeln.de/james.nyomakwa@gmail.com.
}

\footnotetext{
Acknowledgements: I would like to thank Prof. Dr. W. Wessels (University of Cologne) and Dr. C. Damro (University of Edinburgh) for their supervisory comments and suggestions during this research. I am also grateful to all EXACT Fellows for many useful comments and to R. Taylor for helping with proofreading this manuscript. I am grateful for the initial funding for this research by European Commission under the Marie Curie ITN Fellowship and further financial support offered by the Schmittmann-Wahlen Foundation (Cologne-Germany).
} 


\section{Introduction}

The European Union (EU) has a long history of trading with the African, Caribbean, and Pacific (ACP) countries with the purpose of fostering their smooth and gradual integration into the world economy. It is expected that such integration would subsequently facilitate their sustainable development and thereby reduce and eventually eradicate poverty in the ACP region. In line with this aim, in the year 2000, in the context of the Cotonou Partnership Agreement (CPA) reached between the EU and ACP States, a time frame was set for the EU to begin negotiations with the ACP Group for regional Economic Partnership Agreements (EPA) (see ACP Group of States and European Community and its Member States 2000). These negotiations were also partly prompted by the need to comply with a non-discriminatory rule of the World Trade Organisation (WTO). The EU had time until the end of December 2007 to eliminate the preferential treatment that it accorded the ACP States in an effort to ensure their trading relationship complied with the rules of the global trade governing body (see WTO Ministerial Conference 2001). By a unanimous decision, the EU Foreign Affairs Council approved the EPA negotiation mandate for the European Commission on 17 June 2002 and official EPA negotiations subsequently commenced on 27 September 2002 in Brussels with the aim of reaching a conclusion by the end of 2007 at the latest.

The outcomes of the EPA negotiations, however, fell short of that expectation in 2007, and to date, negotiations are ongoing due to strong disagreements between the EU and the stakeholders of the ACP Group over several aspects of the proposed EPAs, the key features of which are outlined below:

The EPAs, according to the Cotonou Agreement which serves as the legal basis for their negotiations, are formed to create full bi-regional Free Trade Agreements (FTAs) between the EU on the one hand, and individual Regional Economic Communities (RECs) of the ACP Group on the other. They are expected to entirely change the trade relations and structure between the partners. They replace existing unilateral, nonreciprocal preferential access to the EU market with reciprocal market access between both partners (European Commission 2002b). This means the ACP countries are expected to reciprocate their trade relationships with the EU by equally liberalising tariffs on EU goods and services entering their markets.

The proposed EPAs are also intended to liberalise trade in goods and services between the parties; improve on Rules of Origin ( $\mathrm{RoO}$ ); and include provisions on trade 
facilitation and Technical Barriers of Trade (TBT). The agreements cover binding rules on investments, competition policy, public procurement, Intellectual Property Rights, and Sanitary and Phytosanitary Measures (SPS). They are also expected to abide by WTO's Most Favoured Nations (MFN) and National Treatment (NT) principles among others, as stated in European Commission (2002b), ACP Group of States (2002), and European Commission (2002a). Overall, the new EPAs are expected to be compatible with WTO rules.

At the time of completing this manuscript (April 2017), the state of the bi-regional EPA negotiations is that out of the six/seven ${ }^{1}$ RECs in the ACP regions, only the Caribbean Forum has signed and implementing a full regional level and a full (trade in goods and services) EPA with the EU. ${ }^{2}$ Negotiations with the remaining six ACP RECs are in various stages and forms as could be observed in both the February and April 2017 Overview of Economic Partnership Agreements published by the European Commission (2017b, 2017c). Typically, in cases where regional-level EPA negotiations have not concluded, some individual ACP countries have signed or initiated interim bilateral agreements with the EU, while awaiting the conclusion of the regional EPAs. Some other countries have refused to sign any form of EPA with the EU as seen in the EPA negotiation updates published by the European Commission (2016) and European Commission (2017b). Table 1 below offers an overview of the ACP regions and their respective countries with an indication of their levels of development in accordance with the United Nations country classifications. The table also shows the state of EPA negotiations.

\footnotetext{
${ }^{1}$ Initially, there were six RECs negotiating the EPAs with the EU. However, the East Africa Community was devolved from the existing Eastern and Southern Africa and Southern African Development Community framework for a separate negotiation.

${ }^{2}$ Per the initial plan, all seven trading blocs in the ACP region were expected to sign and implement the EPAs with effect from 1 January, 2008.
} 
Table 1. List of ACP regions and countries

\begin{tabular}{|c|c|c|c|}
\hline $\begin{array}{l}\text { African, } \\
\text { Caribbean, and } \\
\text { Pacific (ACP) } \\
\text { Region }\end{array}$ & $\begin{array}{l}\text { Least } \\
\text { Developed } \\
\text { Countries } \\
\text { (LDCs) }\end{array}$ & \begin{tabular}{|c|} 
Non-Least \\
Developed Countries \\
(Non-LDCs)/ \\
Developing Countries
\end{tabular} & $\begin{array}{l}\text { State of EPA Negotiations } \\
\text { and Signatures }\end{array}$ \\
\hline $\begin{array}{l}\text { Central African } \\
\text { Economic and } \\
\text { Monetary } \\
\text { Community } \\
\text { (CEMAC) }\end{array}$ & $\begin{array}{l}\text { Cameroon, The } \\
\text { Central African } \\
\text { Republic, DR } \\
\text { Congo, Chad, } \\
\text { Equatorial Guinea, } \\
\text { Sao Tome }\end{array}$ & $\begin{array}{l}\text { Gabon, } \\
\text { The Republic } \\
\text { of Congo }\end{array}$ & $\begin{array}{l}\text { Cameroon is the only country that } \\
\text { has signed EPA and has started } \\
\text { provisional implementation since } \\
4 \text { August } 2014 \text {. }\end{array}$ \\
\hline $\begin{array}{l}\text { East African } \\
\text { Community } \\
(\text { EAC) }\end{array}$ & $\begin{array}{l}\text { Burundi, Rwanda, } \\
\text { Tanzania, Uganda }\end{array}$ & Kenya & $\begin{array}{l}\text { Kenya and Rwanda signed the } \\
\text { Economic Partnership Agreement } \\
\text { on } 1 \text { September 2016. Tanzania } \\
\text { categorical refused to sign it citing, } \\
\text { negative implications on her } \\
\text { industrialisation (Editor 2017:1). } \\
\text { The remaining EAC members } \\
\text { (Burundi, Tanzania, and Uganda) } \\
\text { are expected to decide on their } \\
\text { signature of the EPA in the next } \\
\text { EAC Summit in 2017. }\end{array}$ \\
\hline $\begin{array}{l}\text { Eastern } \\
\text { and Southern } \\
\text { Africa (ESA) }\end{array}$ & $\begin{array}{l}\text { Comoros, } \\
\text { Djibouti, Eritrea, } \\
\text { Ethiopia, } \\
\text { Madagascar, } \\
\text { Malawi, Somalia, } \\
\text { Sudan, Zambia }\end{array}$ & $\begin{array}{l}\text { Mauritius, } \\
\text { Seychelles, } \\
\text { Zimbabwe, }\end{array}$ & $\begin{array}{l}\text { Mauritius, Seychelles, Zimbabwe } \\
\text { and Madagascar signed an Economic } \\
\text { Partnership Agreement with EU in } 2009 \\
\text { and its provisional application started on } \\
14 \text { May 2012. The remaining countries } \\
\text { (Comoros, Djibouti, Eritrea, Ethiopia, } \\
\text { Malawi, Somalia, Sudan, and Zambia) } \\
\text { have either only initialled or still not } \\
\text { signed the agreement due to several } \\
\text { disagreements }\end{array}$ \\
\hline $\begin{array}{l}\text { Economic } \\
\text { Community } \\
\text { of West } \\
\text { African States } \\
\text { (ECOWAS) }\end{array}$ & $\begin{array}{l}\text { Benin, } \\
\text { Burkina Faso, } \\
\text { The Gambia, } \\
\text { Guinea, } \\
\text { Guinea-Bissau, } \\
\text { Liberia, Mali, } \\
\text { Mauritania, } \\
\text { Niger, Senegal, } \\
\text { Sierra Leone, } \\
\text { Togo }\end{array}$ & $\begin{array}{l}\text { Cote d'Ivoire, } \\
\text { Ghana, Nigeria, } \\
\text { Cape Verde }\end{array}$ & $\begin{array}{l}\text { Cote d'Ivoire and Ghana have signed } \\
\text { bilateral EPAs and have provisionally } \\
\text { started implementation. The regional } \\
\text { level agreement concluded in } 2014 \\
\text { is still going through signatures with } \\
\text { Nigeria, Gambia and Mauritania } \\
\text { opposing it. Meanwhile, all the LDCs } \\
\text { are trading with EU under Everything } \\
\text { But Arms scheme, and Nigeria is } \\
\text { trading with the EU under the } \\
\text { Generalised Systems of Preferences } \\
\text { (GSP), while Cape Verde is trading } \\
\text { under the GSP-Plus. }\end{array}$ \\
\hline
\end{tabular}


(continued)

\begin{tabular}{|c|c|c|c|}
\hline $\begin{array}{c}\text { African, } \\
\text { Caribbean, and } \\
\text { Pacific (ACP) } \\
\text { Region }\end{array}$ & $\begin{array}{c}\text { Least } \\
\text { Developed } \\
\text { Countries } \\
\text { (LDCs) }\end{array}$ & $\begin{array}{c}\text { Non-Least } \\
\text { Developed Countries } \\
\text { (Non-LDCs)/ } \\
\text { Developing Countries }\end{array}$ & $\begin{array}{l}\text { State of EPA Negotiations } \\
\text { and Signatures }\end{array}$ \\
\hline $\begin{array}{l}\text { Southern } \\
\text { African } \\
\text { Development } \\
\text { Community } \\
\text { (SADC) }\end{array}$ & Angola & $\begin{array}{l}\text { Lesotho; } \\
\text { Mozambique, } \\
\text { Namibia, Botswana, } \\
\text { Swaziland }\end{array}$ & $\begin{array}{l}\text { Botswana, Lesotho, Mozambique, } \\
\text { Namibia, Swaziland joined by South } \\
\text { Africa (all together constituting the, } \\
\text { EPA SADC States) signed the EPA } \\
\text { with the EU on } 10 \text { June } 2016 . \\
\text { Provisional implementation } \\
\text { commenced on } 10 \text { October } 2016 . \\
\text { Mozambique and Angola are yet } \\
\text { to sign the agreement. }\end{array}$ \\
\hline $\begin{array}{l}\text { Pacific } \\
\text { ACP Group } \\
\text { (PACP) }\end{array}$ & $\begin{array}{l}\text { Kiribati, } \\
\text { the Solomon } \\
\text { Islands, Tuvalu, } \\
\text { and Vanuatu }\end{array}$ & $\begin{array}{l}\text { Cook Islands, Fiji, } \\
\text { The Marshall Islands, } \\
\text { Micronesia, Nauru, } \\
\text { Niue, Palau, Papua } \\
\text { New Guinea, Samoa, } \\
\text { and Tonga }\end{array}$ & $\begin{array}{l}\text { Papua New Guinea signed the EPA } \\
\text { with EU on } 30 \text { July } 2009 \text { and ratified } \\
\text { it on } 25 \text { May } 2011 \text {. Fiji also signed the } \\
\text { EPA with EU on } 11 \text { December } 2009 \\
\text { and started provisional application on } \\
17 \text { July } 2014 \text {. The remaining countries } \\
\text { have so far not signed the agreement } \\
\text { due to persistent disagreements. }\end{array}$ \\
\hline $\begin{array}{l}\text { Caribbean } \\
\text { Forum } \\
\text { (CARIFORUM) }\end{array}$ & Haiti & $\begin{array}{l}\text { Antigua } \\
\text { and Barbuda } \\
\text { The Bahamas, } \\
\text { Barbados, Belize, } \\
\text { Cuba, Dominica, } \\
\text { Dominican Republic, } \\
\text { Grenada, Guyana, } \\
\text { Jamaica, Suriname, } \\
\text { Saint Lucia, St. } \\
\text { Christopher and } \\
\text { Nevis, St. Vincent } \\
\text { \& the Grenadines, } \\
\text { Trinidad and } \\
\text { Tobago }\end{array}$ & $\begin{array}{l}\text { Antigua and Barbuda, The Bahamas, } \\
\text { Barbados, Belize, Dominica, } \\
\text { Dominican Republic, Grenada, } \\
\text { Guyana, Jamaica, Suriname, Saint } \\
\text { Lucia, St. Christopher and Nevis, St. } \\
\text { Vincent \& the Grenadines, Trinidad } \\
\text { and Tobago signed a full and regional } \\
\text { EPA with EU in October } 2008 \text {. } \\
\text { Ratification is far advanced among } \\
\text { the parties. On } 10 \text { December 2009, } \\
\text { Haiti also signed but yet to ratify the } \\
\text { agreement. The provisional } \\
\text { application of that regional EPA } \\
\text { between the EU and the CARIFORUM } \\
\text { started in December } 2008 .\end{array}$ \\
\hline
\end{tabular}

(Source) Author's own compilation based on United Nation's Country Classification and European Union's regional groupings for the purposes of negotiating the Economic Partnership Agreements.

The differences in the state of EPA negotiations as shown in Table 1 are not unexpected. From the inception of the negotiations, whereas the EU has insisted on 
almost all of the proposed provisions in the EPA, the ACP Group in general and the RECs have opposed the inclusion of majority of them. For instance, the inclusion of the so-called 'Singaporean issues', which include public procurement, rules on investment, and competition policy, have been protested because they are considered as non-essential under the WTO rules. Some of these are not even mandated yet at the WTO level (see ACP Council of Ministers 2004, 2005, 2007a, 2007b, ACP-EC Council of Ministers 2008, ACP Heads of State and Government 2008, ACP Council of Ministers 2014, ACP Heads of State and Government 2012). Many of the proposed EPA provisions are thus based on EU's own initiative - EU trade norms. These are accordingly regarded as nonessential to meet the WTO-compatibility aim of the EPAs by the ACP parties (Heron 2011, Borrmann, Großmann, and Koopmann 2006, South Centre 2005).

Additionally, the ACP RECs from the onset demanded additional financial resource commitment from the EU to support their transition to full liberalisation and market access under the proposed EPA regime. The EU, however, refrained from committing to such legally binding additional financial resource until much later in the negotiations (ECOWAS Ministers of Trade and Finance 2003, European Commission 2005a, Frederiksen and Bilal 2004). Almost 10 years after the initial deadline, the EPA negotiations are still ongoing with conflicting views between the EU and the ACP regions.

\section{A. Is there a limit to EU's negotiation power and leverage?}

On the basis of the empirical evidence of the EPA negotiations and the outcomes as shown above, one important question becomes of interest: how come an economically and politically powerful EU would be seen to be 'struggling' to reach a conclusion on international trade agreements with a supposedly economically and politically 'subservient' ACP Group and regions? This question seems relevant as it has been argued that once the EU has successfully established a common market and member countries have transferred powers for international trade negotiations to the European Commission, the EU would usually easily conclude trade negotiations with third parties (Larsén 2007a, 2007b, 2007c, Meunier 2000, 2007, Nicolaidis 1999, Meunier and Nicolaidis 2005, Meunier 2005, Meunier and Nicolaidis 2006, Pollack 2003a, 2003b, Dür and Elsig 2011). This proposition firstly assumes effective internal decisionmaking processes within the EU. Second, it alludes to the general structural theoretical 
assumption that, as a stronger international player with asymmetrical 'structural power' and a huge market incentive, the EU would quickly 'extract' agreements from relatively and structurally weaker third parties (Galtung 1964, 1971, Keohane 1986, Hills 1994, Buzan 2009, Williams 2014, Mearsheimer 2006, Glaser 2003, Waltz 2000, Guzzini 1993).

In other words, from an international political economic perspective, the structural and economic advantage the EU has over the ACP regions would suggest that it has enormous leverage with them and could thus dramatically influence trade negotiations such as the EPAs with them in line with its wishes. This view about EU's influence globally as an 'actor' is also argued by Bretherton and Vogler $(1999,2008)$. In their view, the EU as a 'sui generis' actor in global politics, has the 'presence' (ability to exert influence beyond its borders), 'opportunity' (factors in the external environment that enable or constrain actorness), and 'capability' (the ability of internal policies and context to generate external response by third parties who are affected), as claimed by Bretherton and Vogler (2008, 404 407). These characteristics of the EU would thus make it influential in international trade and political negotiations.

However, pondering over the processes of the EPA negotiations with the ACP regions and countries, and the outcomes so far witnessed, creates doubts on the veracity of such assumptions about the EU's influence and capabilities on the international stage. In many cases, it has crossed 10 years of negotiations after the original deadline, and yet, the regional EPAs and their prospects are in limbo. Instead of regional EPAs, bilateral EPAs have been initiated. Other concluded negotiations have been watered down below the initial proposal.

Article 37 (1) of the Cotonou Partnership Agreement (CPA), which serves as the legal basis for the EPA negotiations, reads:

'Economic Partnership Agreements shall be negotiated during the preparatory period which shall end by 31 December 2007 at the latest. Formal negotiations of the new trading arrangements shall start in September 2002 and the new trading arrangements shall enter into force by 1 January 2008, unless earlier dates are agreed between the Parties' (ACP Group of States and European Community and its Member States 2000).

This Cotonou provision reveals that negotiations have exceeded the initial 2007 negotiation deadline by almost 10 years. Yet, the EPA negotiations between the EU and 
the West African region and the Eastern African Community (EAC) for instance, are in an indeterminate state. Similarly, other regional EPA negotiations are still ongoing. This empirical fact that full regional agreements with majority of the ACP RECs are yet to be concluded and ratified in the face of the EU's asymmetrical power calls for academic enquiry. The reasons for such different negotiation outcomes warrant a rigorous analysis, which constitutes the backbone of this study.

This study is structured as follows. Section II proceeds with a brief overview of the theory of Best Alternative To the Negotiated Agreement (BATNA) in negotiation studies and discusses its usefulness in explaining the case at hand. Section III discusses the 'alternatives to the EPA' as the current EU external trade regime permits. Sections IV and V analyse the impact of the availability or otherwise of 'BATNAs' as identified using two EPA negotiation configurations selected in the study. Finally, Section VI concludes the study with implications of the findings on the EU's external trade policy regime towards developing regions.

\section{Elaborating the Role of BATNA in International Negotiation}

Calling the plausibility of 'conventional' EU-centric theories and concepts used in studying the EU's role in the world to explain the EPA negotiations outcomes into question, this study elaborates on the extent to which the conception of 'BATNA' in negotiation theory helps to explain the differences in negotiation outcomes, such as the outcomes emerging from the EPA negotiations. The focus on BATNA in this study is done with an acknowledgment of the fact that a given negotiation outcome could be attributable to several factors as argued by Crump (2011): 'The outcome of a single negotiation can have multiple explanations depending on the variables selected for analysis' (ibid., 197). To that extent, the aim of this study is to explore the robustness of BATNA as an explanatory variable for the case at hand.

In negotiation studies, several scholars review the role of alternative(s) to a given proposed agreement-what is conceptualised as the 'Best Alternative To the Negotiated Agreement (BATNA)'. Research on BATNA as a means to understanding the negotiation processes and outcomes was pioneered by Fisher and Ury (1981). Subsequently, many others studies have followed, including Sebenius (1984, 1992, 
2006, 2009), Lax and Sebenius (1991), Lax (1985), Odell (2002, 2009, 2010), and Wheeler (2002), among others. Overall, in the negotiation literature, perceived or actual alternative(s) or BATNAs are considered as very crucial to negotiation processes and outcomes. By definition, Fisher and Ury (1981) see BATNA as the 'no-agreement alternative' negotiating parties prefer as against the proposed agreement in order to maximise gains as rational actors. This implies when the values or benefits of the perceived or real BATNA are expected to be higher than those from the currently negotiated agreement, the negotiating parties are likely to reject the negotiated agreement in favour of their BATNA.

It is thus claimed that as rational actors, the negotiating parties demonstrate high interest and commitment to the proposed agreement by quickly concluding it when the alternative to a 'no agreement' makes them worst off as claimed by Odell $(2009,2010)$, Spangler (2012), and Narlikar and Odell (2006, 116 117). This proposition implies that a party's BATNA determines the extent to which it is able to resist proposals from its negotiating partners during the negotiation process - regarding the worst deal it will accept — and hence set the limits of the 'Zone of Possible Agreement (ZOPA)' in the view of Odell $(2010,622)$.

Consequently, it is the BATNA analysis that reveals the 'reservation price' of a proposed agreement, i.e., it provides 'a strict lower bound for the minimum worth required of any acceptable settlement' (Sebenius 1992, 27). It plays a tactical role towards the conclusion of the negotiation - as in, 'The more favourably that negotiators portray their best alternative course of action...the smaller is the ostensible need for the negotiation and the higher the standard of value that any proposed accord must reach' (Sebenius 1992, 27). This assumption means the presence or otherwise of a BATNA directly influences the negotiation process and its outcome. It is thus through the BATNA analysis that negotiating parties can make 'wise' or 'rational' decisions. Negotiating parties are able to 'walk away' from a given negotiation when they perceive it to offer a worse value than what they could gain from a given alternative (Spangler 2012). This also means, conversely, if the current agreement offers a 'favourable' value than the BATNAs, negotiating parties are expected to accept that agreement and conclude it.

Furthermore, having a BATNA in negotiation is deemed as a source of bargaining power and hence it influences the negotiation processes and outcomes. It is often said that in negotiations, 'your best alternative to a negotiated agreement or BATNA, is often your best source of bargaining power' (PON Staff 2016, 1). This means the party with a 
BATNA, utilising the bargaining power obtained, is less likely to make concessions to the opponent. Rather, the party should secure concessions from the negotiating opponent.

Another important element of the BATNA analysis is the consideration of the concept of 'ripeness' which has extensively been discussed by negotiation theorists such as Zartman (2005, 8), Avenhaus and Zartman (2007), and Spangler (2012). 'Ripeness' is said to arise when the negotiating parties move from each other seeking their own unilateral solutions to a situation in which they perceive themselves to be in a hurting stalemate and view a negotiated solution as a possible way out of the conflict (Avenhaus and Zartman 2007, 116). This occurs when both parties begin to identify the necessity to find an agreement to satisfy their mutual interests. If one party considers the value of a BATNA as satisfying than the proposed agreement, the situation of 'ripeness' does not arise.

It is further argued in the international negotiation literature that until it is realised that no BATNA is available or it is worse than what they could obtain from the current negotiation, the negotiating parties might be pursuing a negotiating strategy that uses offensive and/or defensive tactics to claim value from their opponents. At the same time, they will defend themselves against similar claims, especially when the parties' goals are in conflict (Narlikar and Odell 2006, 116 117). In support of this argument, Wheeler $(2002,3)$ has argued that it is 'only by considering the perceived BATNAs of both the potential buyer and seller can one see if agreement is really possible'. By implication, it is by reviewing the BATNAs of the negotiating partners of the case at hand, that the different outcomes could be explained.

Employing the definition and assumptions of BATNA as explained above, this study examines the role of 'real or perceived alternative' to the proposed EPA as an independent variable. It is assumed that the so-called BATNA offers significant explanatory power regarding the development of the EU's negotiations for an EPA with ACP regions in general, and ECOWAS and CARIFORUM in particular. In support of that expectation, Larry Crump has argued that,

'The links between a party's goals and its real or perceived alternative(s) are so fundamental to the negotiation process that they are thought to contribute toeven establish - interdependence between the parties. Alternatives often appear in the form of another negotiation' (Crump 2007, 118).

It is thus justifiable to assume that the aims set up by the negotiating parties (in 
this case the EU and the ACP regions) to embark on and conclude the negotiations of EPA are fundamentally influenced by their real or perceived alternatives. Based on the above suppositions, Section III identifies the possible alternatives to the EPA proposal. However, before delving into these alternatives, a brief description of how BATNA is estimated in the study is outlined.

\section{A. Estimating BATNA}

To calculate and determine BATNA and its impacts is a daunting task. Negotiating parties apart from determining their own BATNAs are expected to equally estimate the BATNAs of their opponents in order to obtain a holistic picture. It is also possible that there are many options available to choose from. To be able to determine the BATNA of a given negotiator as well as that of the opponent, Sebenius (1992), Fisher and Ury (1981), and other scholars suggest employing a 'decision analysis' to help dissect negotiation positions and interests of the parties. Analysts and/or the parties then have to evaluate the benefits expected to accrue from all identifiable alternatives to the current agreement in order to be able to pick the best choice among them that 'totally' satisfies the subjective interest of the given party as argued by Sebenius $(1992,27)$.

In the calculation of BATNA, analysts should also consider the possible costs, impacts, feasibility, and consequences of each option and weigh them against the interest of the negotiating party to arrive at an optimal choice. It is also acknowledged in the negotiation literature that sometimes, there may not be a BATNA available to a given negotiating party, and where there are BATNAs, they may be susceptible to change over time with new information, interpretations, competitive moves, or opportunities (ibid., 27). This means while BATNAs could rightly be identified and used in the decisionmaking process of the negotiations, finding the most appropriate BATNA could be difficult. Moreover, the supposedly most appropriate BATNA may be misleading to the negotiating parties. Taking all these considerations on board, this study calculates stepby-step the BATNA(s) available to the negotiating parties based on the information available.

Both primary and secondary data regarding what the negotiation parties consider as BATNA or 'alternative' to the EPA are gathered and analysed. Furthermore, additional information about alternative(s) to EPA were posed in interviews with policy makers and practitioners who were directly involved in the negotiations and decision making. This 
was done to determine what was perceived as a BATNA (if any) and how it influenced their negotiation positions. In the next section, the identified alternatives to the EPA negotiations are presented.

\section{Alternatives to the Economic Partnership Agreements}

Under the current trade regime of the EU, three alternative arrangements have been identified by several scholars for ACP countries and regions in case of a noEPA scenario: the Generalised System of Preferences (GSP); Generalised System of Preferences Plus (GSP+); or the Everything But Arms (EBA) trading scheme (Bilal and Rampa 2006b, 87). The EU's GSP is a specific trading scheme approved by the UN and WTO which seeks to help Developing Countries (DC) by making it easier for them to export their products to the EU by eliminating or reducing tariffs up to about $66 \%$ of traded goods, as described by European Commission (2014a, 2) and Gasiorek et al. (2010). On the other hand, the GSP+ is a more favourable type of the standard GSP that is given to DCs that are already benefiting from the GSP but have gone ahead to ratify and implement international conventions such as human rights, labour rights, sustainable development, and good governance. Those countries benefiting from GSP + pay zero duties on up to $66 \%$ of goods traded with the EU, as pointed out by the European Commission (2014a, 2 3). Moreover, the EBA, as the name suggests, is a special arrangement for the Least-Developed Countries (LDCs) who are permitted to export everything (every product) except arms into the EU market 'full duty-free, quota-free', as carefully explained in the European Commission (2013, 2014a), Faber and Orbie (2009) and Flint (2008). All the three EPA-alternative trading schemes described are nonreciprocal and are approved by the WTO under the WTO 'enabling clause' which allows for an exception to the WTO 'Most-Favoured-Nations' (non-discrimination) principle.

Despite the three alternative trading schemes outlined above, at the general ACP-EU level of negotiation, a long-drawn debate ensued between the EU and the ACP regions on 'alternatives' to the EPA as proposed. This was the case, even though article 37(5 6) of the Cotonou Partnership Agreement which gave rise to the EPA negotiations indicates the following on trading options: 
'Negotiations of the Economic Partnership Agreements will be undertaken with ACP countries which consider themselves in a position to do so, at the level they consider appropriate and in accordance with the procedures agreed by the ACP Group, taking into account regional integration process within the ACP; In 2004, the Community will assess the situation of the non-LDC which, after consultations with the Community decide that they are not in a position to enter into Economic Partnership Agreements and will examine all alternative possibilities, in order to provide these countries with a new framework for trade which is equivalent to their existing situation and in conformity with WTO rules' (ACP Group of States and European Community and its Member States 2000).

This implies that before the negotiations commenced, it was acknowledged and anticipated that some ACP countries and regions could possibly consider themselves not to be in a position to negotiate EPA with the EU. Meanwhile, before and during the EPA negotiations, there was consistent reiteration by many ACP countries and negotiators about their lack of readiness to negotiate EPA and attempted to explore its 'alternatives' as was originally anticipated in the Cotonou Agreement (Bishop, Heron, and Payne 2013, West African Civil Society Institute 2013, Economic Justice Network of Ghana 2012, Raihan, Razzaque, and Laurent 2007, Bilal and Rampa 2006a, 2006b, Wallie 2005, ACP Heads of State and Government 2012: para. 36, AU Conference of Ministers of Trade 2006, 2007, AU Conference of Ministers of Trade and of Finance 2008, African Union 2011). It is thus baffling that the two parties had different positions on the EPA alternatives. However, the explanation for such behaviour is not far-fetched due to the considerations below.

The EU being a proponent of the EPA policy did not want to emphasise on its alternatives, since doing so would amount to shooting the new policy in the foot. Rather, the EU perceived the EPA as a modern trade regime that was and still is the best policy to bring about the development of the ACP regions and, at the same time, good for its own economy. In official statements and documents, it was observable that the EU did not consider the 'alternatives' of EPA beyond stating them in the Cotonou Agreement. For instance, Mr Peter Mandelson (the then EU Trade Commissioner) is widely quoted on his 'There is certainly no Plan B to EPA' comment made in 2007 (ECDPM 2007, 1). See Wallie $(2005,9)$ and South Centre $(2009,3)$ for the account of other official statements to the effect of 'no alternatives to EPA' from the EU perspective. On the other hand, the 
ramifications of the proposed EPA seemed daunting for the ACP Group. This is because several proposals enshrined in the EPA as described above were considered inimical to their developmental aspirations. Thus, the ACP Group preferred to maintain the status quo.

Notwithstanding the inconsistency described above, an even puzzling development is that regardless of the ACP Group's perceived lack of readiness for EPA and their reluctance to the negotiations, the Group endorsed an EPA joint review report issued by both EU and the ACP Group in July 2007. In this report, the latter failed to make categorical demand for the consideration of EPA alternative (ACP Group of States and European Union 2007). Instead, paragraph 2.4 of the report partly states that '....all of the six joint EPA regional reviews confirm the commitment of the parties to conclude negotiations by the end of 2007 as stated in the Cotonou Agreement' (ibid., 5). On the hindsight, we see that that commitment by the parties was overly ambitious. However, it is observable that in spite of the reservations, there was some level of goodwill among the ACP regions to continue with the negotiations with the hope of getting their concerns addressed.

In conclusion, it is necessary to point out that the disagreements between the parties persisted on several issues which resulted in mixed negotiation outcomes by the end of 2007 and until date, as found by Stevens, Meyn, and Kennan (2008), ODI and ECDPM (2008), Kwa, Lunenborg, and Musonge (2014), and recently by the European Commission (2017b). In the subsequent sections, an effort is made to explain these mixed results. Using two ACP regions under comparison, this study determines how the availability of EPA alternative(s) influenced their respective bi-regional EPA negotiations, using the theory of BATNA. We begin with the case of the EU negotiations with the Caribbean Forum.

\section{The Impact of BATNA in EU-CARIFORUM EPA Negotiations}

In line with the aim of this study to evaluate how the availability of what is considered to be a 'Best Alternative' trading scheme, the so-called BATNA, actually influenced the EPA negotiation processes and outcomes, the case of EU-Caribbean Forum negotiations is considered in this section. This study finds that the CARIFORUM did not have a BATNA in place to the proposed EPA; hence, their rational and strategic choice was to establish a new trade agreement with the EU in the form of an EPA. 


\section{A. No BATNA situation for CARIFORUM}

The negotiators of the CARIFORUM realised that without signing the EPA with the EU, the region would have had to choose to trade under one of the three alternative trading regimes outlined earlier, namely, the EBA, GSP, or GSP+. Of the three, the EBA is considered as the most favourable because countries do not have to do anything to benefit from it. Countries are placed under the EBA scheme by virtue of being classified as a Least Developed Country (European Commission 2013). However, none of the CARIFORUM member countries, except for Haiti, qualify for the EBA scheme, as could be seen in Table 2 below. In the absence of EPA, the remaining 14 countries had the option to trade with the EU either under the GSP or the GSP+ scheme. Even though the GSP+ remained an option, by 2008 no ACP country was eligible according to the rules of the EU (Fontagné, Laborde, and Mitaritonna 2008b, 49). ${ }^{3}$

Table 2. Alternative trade regimes

(Available to the Caribbean Forum member states in the absence of EPA)

\begin{tabular}{|l|c|}
\hline \multicolumn{1}{|c|}{ Country } & Alternative to EPA \\
\hline 1. Antigua and Barbuda & GSP \\
\hline 2. The Bahamas & GSP \\
\hline 3. Barbados & GSP \\
\hline 4. Belize & GSP \\
\hline 5. Cuba & Not party to the EPA \\
\hline 6. Dominica & GSP \\
\hline 7. Grenada & GSP \\
\hline 8. Guyana & GSP \\
\hline 9. Haiti & EBA \\
\hline 10. Jamaica & GSP \\
\hline 11. St. Kitts and Nevis & GSP \\
\hline 12. Saint Lucia & GSP \\
\hline 13. St. Vincent and the Grenadines & GSP \\
\hline 14. Suriname & GSP \\
\hline
\end{tabular}

3 For the 27 List of Conventions that must be ratified to qualify for GSP+, see European Commission (2005b) 
(continued)

\begin{tabular}{|l|c|}
\hline \multicolumn{1}{|c|}{ Country } & Alternative to EPA \\
\hline 15. Trinidad and Tobago & GSP \\
\hline 16. Dominican Republic & GSP \\
\hline
\end{tabular}

(Note) EPA, Economic Partnership Agreement; GSP, Generalised System of Preferences (trading scheme); and EBA, Everything But Arms (trading schemes of the European Union).

(Source) Own compilation.

Sharing his view on the two remaining options for the CARIFORUM, Lodge (2002, 3) maintained that, 'in spite of the investment of considerable thought, the Caribbean region has not detected any attractive alternative to regional based EPAs (REPAs)'. The Caribbean region thus had limited choice when negotiating EPA with the EU. One alternative to the EPA, the GSP+, was considered to be 'both unattractive and implausible for a number of reasons' (ibid.). He alluded this to three reasons. First, it was and still is a unilateral trade preference offered by the EU and could be 'summarily withdrawn by the EC' (ibid.). Second, there was a sense of uncertainty regarding the GSP system because the EU had 'promised to overhaul its GSP scheme in 2004'. Thus, the region could not rely on that option (ibid.). Third, it was 'doubtful whether a Generalized System of Preferences (GSP) scheme will deliver the degree of market access' (ibid.) enjoyed by the Caribbean region.

The above assessment by Lodge (2002) is shared by several others such as Gonzales (2008, 2) and Fontagné, Laborde, and Mitaritonna (2008a). The latter argue that the main alternative to EPA available to non-LDC ACP countries (such as there are in the CARIFORUM) is the GSP scheme (Fontagné, Laborde, and Mitaritonna 2008b, 39). On the other hand, they could opt for the more attractive GSP+ scheme if they have committed to a sustainable approach to development, by ratifying and implementing a series of international conventions (ibid.). Nevertheless, as has been pointed out earlier, the two options were not considered in the most favourable of terms. These assessments thus left the Caribbean region with no BATNA to the EPA as proposed by the EU.

The analysis above implies that the negotiators of CARIFORUM walked into the negotiations of EPA with the aim to conclude it at all cost. Because the region had no alternative to the EPA, the negotiators needed to strike a deal with the EU by end of the 2007 deadline. Doing so would ensure the region's continued access to the EU market. This assessment was confirmed by a former Caribbean negotiator during an interview on 16 July 2015 in Brussels. As the negotiations peaked at the time of the global economic 
and financial crises in 2008, when the region was experiencing severe economic challenges because of a dip in the commodity prices, it could not afford further economic and trade challenges with its second most important trading partner.

\section{B. Protecting CARIFORUM's market access into the EU}

In addition to the fact that the Caribbean countries did not qualify for the EBA and the unilateral nature of EU's GSP schemes made them unattractive, many experts opined that trading under both the GSP and the GSP+ would result in less market access for Caribbean exports to the EU:

'Although, on the one hand, this solution would be fully WTO compatible, as the GSP is legally justified under the Enabling Clause, on the other side, it will not grant to the ACP the same level of preferences that they currently enjoy. Both the GSP and GSP plus provide for a less favourable treatment' (Fontagné, Laborde, and Mitaritonna 2008b, 39).

It was thus estimated that choosing the GSP option would cost 'Caribbean and Pacific' countries a decrease in exports of approximately up to 3 billion US dollars (Bouet, Laborde, and Mavel 2007, 7). This is because the choice of GSP/GSP+ would have meant that exports from some CARIFORUM member states to the EU would attract higher tariff according to several studies, including that published by the Overseas Development Institute (2007). Other studies confirming this claim include Barfod (2015), Herz and Wagner (2010), and Bishop, Heron, and Payne (2013). The 2007 study by the Overseas Development Institute for instance shows that even though wide variations were expected in tariffs applying to different countries and different goods, a switch to a GSP regime would have meant that almost all Caribbean countries would have experienced 'moderate or large tariff jump' in their exports to the EU (ibid., 8 9). Some countries such as Belize could have paid as much as over $75 \%$ tariff on some exports, while St Kitts could have paid over 50\% on some of its exports (ibid., 9). Conversely, in the case of signing the EPA with the EU, none of such tariffs was to be incurred:

'The EPA removes all tariffs and quotas on Caribbean exports to the EU immediately. The only exception is sugar and rice, which will be liberalised 
over short periods' (European Commission 2008a, 2).

Given these clear costs and benefits of EPA and non-EPA, it would have been unreasonable for the Caribbean region not to sign the EPA.

\section{Caribbean agricultural exports and EU's commodity protocol reform}

A related reason for which CARIFORUM had no BATNA and hence concluded the EPA with the EU could be attributed to its circumstance regarding agriculture exports. The region during the period leading to and during the EPA negotiation was faced with major challenges arising out of preference erosion and weak international competitiveness of traditional agricultural exports; low living standards of the rural population; and rapid increase in food imports generated by economic growth, urbanisation, and tourism (Girvan 2007, 22). The period preceding the signing of the EPA between the CARIFORUM and the EU was one that could be described as 'panic' in reaction to external events. In a speech around the time, the Chairperson of the Caribbean Community stressed the fate awaiting the Caribbean region with regards to economic earnings from banana and sugar and consequently outlined and emphasised the need for 'new sources of export and foreign exchange earnings' for the region to survive (CARICOM Secretariat 2006, 1).

It is thus clear that the erosion of commodity preference contributed to rendering a limited choice for manoeuvre under the circumstance, as was assessed by Fontagné, Laborde, and Mitaritonna (2008b, 39). They postulated that, 'The Caribbean and Pacific regions will also see strong impacts from the reduction in their preferential margins on sugar and bananas, key exports from both regions' (ibid.). With an unfavourable alternative to EPA, the Caribbean negotiators and governments thus decided to sign, to date, the most comprehensive EPA with the EU covering trade in goods, trade-related issues, and trade in services among others as a measure to prevent a regional economic collapse in the Caribbean region.

From the ongoing analysis, it is clear that CARIFORUM did not have a BATNAa favourable trading scheme with the EU other than the proposed EPA. The absence of a BATNA therefore fundamentally influenced the negotiations. This evidence goes to support the assumption in this study that the nature of the EPA negotiation outcome is dependent on the availability or otherwise of a 'best alternative' to the proposed 
agreement, as hypothesized in the negotiation theory. It can thus be claimed that the EU's bi-regional EPA negotiation with a third party does not conclude on time when that third party (REC) has a BATNA. In this section, it has been shown that the EU-CARIFORUM EPA concluded in 2007 because CARIFORUM did not have any other 'better alternative' trading scheme that would have served the region's interest. Concluding the EPA was thus their BATNA. In the next section, this study conducts a similar assessment of the role of a BATNA in the negotiations involving EU and ECOWAS.

\section{The Impact of BATNA in EU-ECOWAS EPA Negotiations}

Unlike the CARIFORUM-EU EPA negotiations which were concluded in 2007 and signed in 2008, the ECOWAS-EU EPA negotiations have continued until date. There was a trade-in-goods-only agreement reached in 2014, although it has still not been signed by several countries in the ECOWAS region. Based on the assumption of BATNA in the negotiation theory, it is argued here that the ECOWAS-EU EPA negotiations have not concluded after many years of negotiation because most West African countries have a better alternative (BATNA) to the EPA in the form of the 'Everything But Arms' trading scheme.

\section{A. All but two West African countries have BATNAs to the EPA}

The EBA scheme is a BATNA for majority of the ECOWAS members. As explained earlier, EBA offers 'Duty-Free-Quota-Free' market access for all exports from LDCs. Since majority of the countries participating in the EPA negotiations with EU are classified as LDCs, these countries have not shown to have any incentive to conclude the EPA with the EU (Overseas Development Institute 2007, 2, European Commission 2013, Faber and Orbie 2009, Faber and Orbie 2007). However, why do the LDCs in ECOWAS prefer the EBA to the EPA? It is because the EBA alternative applies to these West African LDCs at no adjustment costs unlike the adjustment costs associated with the proposed EPA. Under that trade regime, the qualified countries are not required to abolish their import duties as required by the EPA. The countries will also not be 
required to reciprocate whatever EU offers them, as is the case under the proposed EPA. Indeed, predominantly consisting of LDCs, the economic and social development circumstances of individual ECOWAS countries do not offer the incentive for the negotiations of the EPA with the EU.

Apart from a commitment to negotiate together as one West African economic bloc in order to promote their internal regional integration in response to the EU's proposal, it appears the individual ECOWAS countries would have had other priorities excluding seeking to establish a reciprocal FTA with the EU. The region, as a result, appeared not keenly interested and ready to negotiate the EPA as proposed by the EU covering many issues including the so-called 'WTO-plus' 'Singaporean issues' (rules on investment, competition rules, public procurement, and trade facilitation). Further analysis of the impact of the EBA alternative before and during the EU and ECOWAS negotiations is presented below.

As could be referred from Table 1 above, 12 out of 16 ECOWAS countries participating in the EPA negotiations with the EU are classified as LDCs. This implies by default they are qualified to trade with the EU under that trading scheme as demonstrated in Table 3 below. From Table 3, it is seen that apart from Cote d'Ivoire, Cape Verde, Ghana, and Nigeria, all the other countries do qualify to trade under EU's generous 'Everything But Arms (EBA)' scheme.

\section{Table 3. Alternative trade regimes}

(Available to the ECOWAS member states in the absence of EPA)

\begin{tabular}{|l|l|}
\hline \multicolumn{1}{|c|}{ ECOWAS Member State } & Alternative to EPA \\
\hline 1. Benin & EBA \\
\hline 2. Burkina Faso & EBA \\
\hline 3. Cape Verde & GSP+ \\
\hline 4. Côte d'Ivoire & GSP \\
\hline 5. The Gambia & EBA \\
\hline 6. Ghana & GSP \\
\hline 7. Guinea & EBA \\
\hline 8. Guinea-Bissau & EBA \\
\hline 9. Liberia & EBA \\
\hline 10. Mali & EBA \\
\hline
\end{tabular}


(continued)

\begin{tabular}{|l|l|}
\hline \multicolumn{1}{|c|}{ ECOWAS Member State } & Alternative to EPA \\
\hline 11. Niger & EBA \\
\hline 12. Nigeria & GSP \\
\hline 13. Senegal & EBA \\
\hline 14. Sierra Leone & EBA \\
\hline 15. Togo & EBA \\
\hline 16. Mauritania* & EBA \\
\hline
\end{tabular}

(Note) (i) ECOWAS, Economic Community of West-African States; EPA, Economic Partnership Agreement; GSP, Generalised System of Preferences; GSP+, Generalised System of Preferences Plus; and EBA, Everything But Arms (trading scheme).

(ii) *: only negotiates EPA under ECOWAS but not a member of Bloc.

(Source) Own Compilation.

Twelve ECOWAS countries therefore do not have any incentive to sign on to the EPA regime all this while. Consequently, the entire West African region signing on to the EPA appeared unlikely from the onset.

Rather, it was anticipated that the remaining four countries that did not qualify for EBA would readily sign on to the EPA, but these countries were divided on the EPA subject. Eventually, only Ghana and Cote d'Ivoire concluded individual bilateral interim EPAs with the EU by the end of the initial deadline, whereas Nigeria and Cape Verde completely abstained. By not having a BATNA to the proposed EPA, Ghana and Cote d'Ivoire signed their 'stepping stone EPAs' with the EU with the hope that the EU-ECOWAS regional-level negotiations would eventually conclude and would replace those bilateral EPAs (Delegation of the European Commission in Ghana 2007, Third World Network - Africa 2009). However, this hope of Ghana and Cote d'Ivoire remains unfulfilled. The EU-ECOWAS regional EPA negotiations have been ongoing until date with some countries protesting the EPA even in its minimalist form as it is. Consequently, this situation compelled Cote d'Ivoire and Ghana to ratify their respective EPAs on 12 August 2016 and 3 August 2016, respectively, in a desperate attempt to safeguard their market access into the EU (Delegation of the European Union to Ghana 2016, European Commission 2017c).

Regarding why Nigeria and Cape Verde have abstained from the EPA, it is observed that they both have their own BATNAs to the EPA as well. Whereas Nigeria currently 
trades with the EU under GSP, it mainly exports crude oil to the EU on the basis of the 'Duty-Free-Quota Free' scheme. It is thus only Nigeria's non-oil exports that are subject to tax (European Commission 2014b). As non-oil products such as cocoa and textiles constitute a small portion of exports, a non-endorsement of EPA benefits Nigeria in the meantime. It avoids all its controversial provisions such as reciprocal market access, trade in services, and rules on investment, among others. Nigeria thus also has a BATNA to the EPA in the form of trading under the GSP scheme.

Cape Verde on its part currently trades under the GSP+ scheme due to its good governance and human rights records. The GSP+ as explained earlier offers a zero-tariff benefit to the beneficiary up to about $66 \%$ of exports. This implies Cape Verde is granted free access to the EU market for all major exports, including fish and fish products which constitutes the country's major export items (81\% in 2016) (European Commission 2017a, 2). Hence, Cape Verde equally has a BATNA to the EPA in the form of the GSP+ scheme. These conditions explain why Nigeria and Cape Verde have refused to sign any form of bilateral EPA with the EU.

Without discussing the diverse national preferences here, it suffices to say that those preferences evolved into a regional negotiating behaviour during the EU-ECOWAS EPA negotiations. Now, let us consider how the availabilities of the BATNAs influenced the EPA negotiation processes and outcomes at the ECOWAS regional level.

To reiterate the state of EPA negotiations between the EU and ECOWAS, currently, two countries have signed and have started provisional implementation of their bilateral interim EPAs with the EU; 12 countries are trading under EBA; one country (Nigeria) is trading under GSP; and one country (Cape Verde) is trading under GSP+. Meanwhile, the regional-level goods only EPA concluded in July 2014 is under consideration with some countries (namely, Nigeria, Gambia, and Mauritania) protesting against it (Bruce 2016). Overall, we can say the future of the regional EPA between EU and ECOWAS is in limbo.

The question that then arises is how did this situation develop? How come the Caribbean Forum signed its EPA with the EU in 2007 but that of the West African region is still in limbo? We argue that it is due to the availability of 'better alternative' trading schemes to the latter, as propounded in the negotiation theory.

From the onset, the West African and EU EPA negotiations were seen to be crucial. This is mainly because there is a high trade-dependent relationship between the two parties. The fact that West Africa accounts for almost $40 \%$ of EU trade within the ACP group meant that much was at stake in the negotiation for both parties. Considering 
the asymmetrical levels of development between the two regions, it was expected that the West African region would be at the losing end. Certainly, the region has sought to protect its interest by taking tough negotiation positions on many of the proposed negotiations put forward by the EU. On the other hand, it is not surprising that the EU would hold on to the negotiation for many years and not give meaningful concession to the West African party to conclude the negotiation. Both parties have been trying harder to obtain a larger share of the EPA pie. Moreover, as the regional negotiations with all the ACP regions were taking place concurrently, the EU was careful not to offer any concession to West Africa that would set a bad precedence for its current and future trade negotiations.

Further, a welfare and economic impact analysis undertaken by Karingi et al. (2005) found that the balance between 'trade creation' and 'trade diversion' ${ }^{4}$ in the scenario of an established Free Trade Area was almost negative for the entire ECOWAS region. Karingi et al. (2005) found that the proposed EPA regime would result in rapid trade creation effects for EU producers and exporters. The EU was going to benefit through a stronger growth of its exports into countries such as Nigeria, Ghana, Cote d'Ivoire, and Senegal (Karingi et al. 2005, 70). In terms of trade diversion, implementing an EPA in ECOWAS was expected to substantially divert trade especially in Ghana and Nigeria to the tune of 102 million US dollars and 173 million US dollars, respectively, in favour of the EU. Those were not appealing statistics on the EPA for ECOWAS's policy makers and the negotiators, thus increasing their hesitation to endorse the deal for many years.

The above scenario that the region would not be gaining much under current circumstances from the EPA fuelled apprehension against it both in private and official circles. There was a feeling of compunction to negotiate a deal not wanted and needed (Coomson 2005, Third World Network-Africa 2005b, Civil Society Organisations against EPA 2012, Global CSOs against EPA 2013, Third World Network-Africa 2005a, Berthelot 2014, CACID 2013, CONCORD 2015, Diarra 2015, ECOWAS Ministers of Trade 2011). Indeed, since the negotiations of the EPA commenced, there has hardly been any public support for it in Ghana-with the exception of a statement by IMANI Ghana (2014). The situation is not entirely different across the region due to a strong civil society opposition to the EPA (Economic Justice Network 2014, West

\footnotetext{
${ }^{4}$ Trade creation is a term used to refer to a situation where after the creation of Free Trade Area (FTA), the resulting elimination of tariffs also results in a replacement of expensive domestic production by cheaper imports from more efficient partner countries. Trade diversion, conversely, occurs when there is a replacement of cheaper initial imports from lower-cost producers outside the FTA to lessefficient producers who are member countries of the FTA.
} 
African Civil Society Platform on Cotonou Agreement 2013, Global CSOs against EPA 2013, Third World Network - Africa 2013, West African Civil Society Platform 2013, West African Civil Society Institute 2013).

As postulated in the negotiation theory under the conception of BATNA, negotiation parties in the process of negotiations do analyse their benefits and costs. When the costs are deemed to be more than the benefits and if the parties will be worse off under the agreement, a walk-away condition is created (Narlikar and Odell 2006, 116 117) and thus there will be no agreement. This cost-benefit analysis was not missing in the ECOWAS region, since the EPA negotiations commenced until date. In this case, the concerned parties did not part ways, but the availability of BATNAs has resulted in prolonged EPA negotiations.

Nevertheless, in terms of the cost-benefit analysis, it was well documented that West African countries would incur higher export tariffs under GSP/GSP + trading schemes (Overseas Development Institute 2007, 8). The optimal choice for them was thus to allow the qualified member states to opt for EBA (ibid.). At the same time, the few nonLDCs would go for a GSP scheme or negotiate a joint EPA if the region wanted to avoid a breakdown in its regional integration efforts ( ibid.). Despite those dynamics against the negotiations of the EPA, the region hesitantly continued with the negotiations until date. The status of that EPA negotiation is hence not unanticipated.

\section{B. High expected adjustment costs and high revenue loss}

West Africa's continued hesitation in the EPA negotiations also had to do with the expected adjustment costs and revenue loss under the proposed EPA. For instance, in its 'Statement Against the signing of EPA', the Economic Justice Network pegged the annual expected revenue loss for the entire ECOWAS region at 1.8 billion US dollars due to the elimination of import duties under EPA (Myjoyonline.com 2014). In this statement, it was highlighted that Ghana, for example, was expected to lose 300 million US dollars annually. This expected revenue loss was being compared to the EPA support of 6.5 billion Euros the EU reluctantly promised to offer to the whole region over a period of five years when they signed it (ibid.).

Similarly, available data on the revenue loss under EPA regime estimate that the West African governments would be losing about 980 million US dollars with dire consequences on other government social programmes (Karingi et al. 2005, 73). Karingi 
et al. (2005) found that 'in terms of evaluating the EPAs for ECOWAS countries at least, it can be noted that the revenue foregone is likely to have negative impacts on other government programmes' (ibid., 72). See Table 4 below for an overview of revenue loss expected under the EU-ECOWAS EPA regime.

Table 4. Loss of revenue implications of an EU-ECOWAS EPA

(Million US dollars)

\begin{tabular}{|l|c|}
\hline \multicolumn{1}{|c|}{ Country } & Revenue Shortfall \\
\hline 1. Ghana & $-193,683,365.00$ \\
\hline 2. Burkina Faso & $-22,003,937.50$ \\
\hline 3. Benin & $-39,523,104.00$ \\
\hline 4. Cote d'Ivoire & $-112,236,538.00$ \\
\hline 5. Guinea-Bissau & $-1,990,216.50$ \\
\hline 6. Senegal & $-80,203,188.50$ \\
\hline 7. Niger & $-20,487,214.00$ \\
\hline 8. Nigeria & $-426,902,557.50$ \\
\hline 9. Mauritania & $-14,572,779.00$ \\
\hline 10. Mali & $-33,141,747.00$ \\
\hline 11. Togo & $-35,471,728.00$ \\
\hline 12. ECOWAS & $-980,216,374.50$ \\
\hline
\end{tabular}

(Note) WITS, World Integrated Trading System; SMART, Partial Equilibrium Simulation Tool; EU, European Union, ECOWAS, Economic Community of West-African States, and EPA, Economic Partnership Agreement.

(Source) Karingi et al. $(2005,73)$ based on WITS/SMART Simulations

As could be seen from Table 4, Nigeria, Ghana, Cote d'Ivoire, and Senegal were expected to lose maximum revenues under EPA. This revenue loss concern was overall a highly sensitive issue for the West African governments and EPA negotiators. This concern partly accounted for ECOWAS's insistence on a guaranteed 'financial resource' from the EU before giving their assent to the EPA (ECOWAS Ministers of Trade and Finance 2003). The concern was again confirmed in interviews with some West African EPA negotiators on 6 March 2012 in Abuja, Nigeria.

From the on-going analysis, it is clear that there was thus an entrenched perception in 
West Africa - similar to other African regions - that the EPAs would not be beneficial to the region. It was thus widely articulated that the EPA comes rather with devastating welfare implications in terms of adjustment costs and revenue losses to the government and people of the region at least in the immediate to medium term. Here it is argued that by undertaking a cost-benefit analysis, the West Africa negotiators were aware of and preferred the various trading schemes that the individual countries could fall back on in case the EPA negotiations failed.

It is thus argued here that, another impact of the EBA, GSP, and the GSP+ alternatives is seen in the bargaining power it offered to the ECOWAS region and the disincentive it created for the West African negotiators to make serious concessions to the EU in the EPA negotiations, however unpalatable that would have been to the region. This is even more so when compared to the time it took to agree on some issues and the limited nature of the EPA that was concluded in 2014 which is still not signed by all countries. It is seen that the availability of BATNAs for the West African states cushioned the region's negotiators against the negotiating pressure pushed by the EU (Fellowship of Christian Councils and Churches in West Africa 2014, EurActiv 2013, Griffith et al. 2007).

\section{Prevailing EPA alternatives offered bargaining power to ECOWAS}

Furthermore, it is argued that being empowered by its alternatives to the EPA the ECOWAS region made provisions to support its member states that would be affected by higher tariffs in case they were placed on GSP by the EU. It is recalled that in their readiness to boycott the EPA deal, the ECOWAS Ministerial Monitoring Committee during a meeting in Accra in November 2011 established a Solidarity Fund through which individual member states that suffered penalty from the EU were to be supported. This move represents how ECOWAS intended to resolve the issue in the face of EU pressure and remained adamant in its demand for a fair and equitable EPA in consonance with the region's developmental aspirations (Ghana Trade Union Congress et al. 2012, ECOWAS Ministerial Monitoring Committee 2011, ECOWAS Ministers of Trade 2011).

We can therefore say that the delay in the decision of the ECOWAS region to sign a partial 'trade in goods only' EPA eventually in 2014 (which has since been put on hold due to persistent opposition by Nigeria, Gambia, and Mauritania) was arguably, on their 
own volition principally to keep the spirit and momentum of the region's integration efforts. We see a clue of that assessment from this proposition by the ECOWAS Ministerial Monitoring Committee warning the region about the dangers of multiple trading regimes to their integration efforts:

'If these two countries ratify the interim EPA while the comprehensive regional Agreement has not been concluded between WA and the EU, the regional integration process runs the risk of being thrown off balance because of the different trade regimes which would co-exist in the region' (EBA for the 12 LDCs, GSP for Nigeria and probably for Cape Verde, EPA Ghana and EPA Côte d'Ivoire) (ECOWAS Ministerial Monitoring Committee 2011, 9; emphasis added).

At that time, ECOWAS's Common External Tariff (ECOWAS CET) was on the verge of being adopted and it was perceived that the entry into force of separate Free Trade Agreements between Côte d'Ivoire, Ghana, and the European Union would be detrimental to trade integration in the region ( ibid.). If that were to happen, 'it would be impossible to build a Customs Union and a Common West African Market, which are, the founding treaties of ECOWAS and UEMOA' (ibid.). Unfortunately, that scenario has become the reality now that the West Africa-EU EPA is in limbo.

Eventually, the clear appreciation of issues at hand by the Ministerial Monitoring Committee of ECOWAS and the fear of negative impact that a non-EPA scenario painted for the regional integration efforts built over several decades would go a long way to create the necessary momentum for the ECOWAS-EU EPA negotiations to go forward at that time. However, the continued impasse between EU and ECOWAS over even the partially initialled regional 'goods-only EPA', suggests that the agreement may not see the light of day in the foreseeable future.

From the on-going analysis, it is deduced that the lack of finality of the ECOWASEU EPA as witnessed after over 13 years of negotiation is due to the presence of 'best alternative trading schemes' available to countries in the region in the form of BATNAs which are perceived to be better than the proposed EPA. This evidence of no conclusion to the agreement facilitated by the presence of BATNA for the majority of the region's member states supports the assumption that that bi-regional EPA negotiation fails to conclude when a party, in this case a Regional Economic Community, has real or perceived better alternative(s) and vice versa. 
It is subsequently claimed that in line with the concept of BATNA in negotiation analysis, the ECOWAS region has been able to 'walk away' from EPA for over 13 years because majority of its membership have BATNAs to the EPA. The BATNA concept thus offers a high explanatory power to the West Africa-EU long drawn-out EPA negotiation processes and the non-concluded outcome.

\section{Conclusion}

Over 16 years ago, the European Union adopted and proposed the Economic Partnership Agreement to replace its external trade relations with the ACP Group of States comprising 79 countries. The results of this study suggest that the EPA policy and its goals have not been executed successfully. Moreover, the EPA policy has not been consistent with EU's own existing external trade schemes. This shortfall has created a disincentive for some ACP regions and countries to own and adopt the EPA as an instrument for their economic and social development.

The role of BATNA in the negotiation processes and outcomes as analysed in this study has been found to be important in explaining the EPA negotiation outcomes. The BATNA-based assumption has therefore been demonstrated to hold: the availability or otherwise of a BATNA in negotiations influences the negotiation processes and its outcomes. As showcased by the two empirical cases studied, third parties negotiating with the EU shift their negotiation behaviours based on the assessments of their BATNAs. As postulated in the negotiation theory, a worst-off alternative (BATNA) causes the parties to have high interest in concluding the proposed agreement and vice versa.

Furthermore, by their different negotiation outcomes, and hence the success rate, it is seen that the merit of the EPA as proposed by the EU has been disputed by the countries that were supposed to benefit from them. Instead, this study has shown that some regions and countries prefer to trade under the old and existing trade regime. The EU, therefore, needs to review how and why the old trade regime seems preferable. At the same time, the EU needs to undertake a holistic review of the EPA policy after negotiating it for over 16 years with mixed reactions from among its key beneficiaries. A review is even more necessary since the last time there was a joint review of the EPA between the 
EU and the ACP Group was between July 2006 and July 2007 (ACP Group of States and Council of the EU 2006, ACP Group of States and European Union 2007). A decade after that review, the time is appropriate for another review to address the policy incoherencies that have emerged with that common commercial policy.

The overall implication of the findings of this study is that the EU would need to go beyond its market size attraction and institutional advantages to properly analyse the BATNA scenario of its negotiating opponents. Doing so will contribute to making the EU an effective negotiator. The brouhahas that have surrounded the EPA negotiations have cast doubts over the effectiveness of the EU trade negotiation in relation with developing countries. They also show that the operationalisation of EU's commercial trade policy instruments and strategies towards developing countries - namely, the GSP, the GSP+, and the EBA - are incoherent with the new EPA policy. Beyond the reforms of the GSP policy in 2004, 2006, and 2012 as recorded in the European Commission (2014a), the EU needs to rationalise them alongside the EPA policy in relation with the ACP Group and other developing countries.

Presently, the EPA policy is designed to appeal to all the ACP countries irrespective of their level of development. It has been presented as the best instrument meant to facilitate the smooth and gradual integration of the ACP countries into the world economy (European Commission 2002b, 2008b). Nevertheless, the mixed negotiation outcomes show that EU's partners have not fully appreciated and accepted its validity as a trade and development instrument that meets their development aspirations in the immediate-to-long-term period. The EU appears to have failed to properly consider how its trading partners in the ACP regions could trade off one of its own trading scheme for another based on national circumstances and interests. For the EPA to be a successful and attractive scheme to developing regions such as the ACP Group, the EU could have modelled it as a replacement for the existing GSP schemes by involving its partners in the WTO. Doing so could have attracted the full support of the ACP Group and prevented their apparent and persistent preference for WTO multilateral trade scheme to the EPA (UNECA 2007, WTO Negotiating Group on Rules 2005, South Centre 2005, ACP Group of States 2004, Bilal 2003, Permanet Delegation of the European Commission to the WTO 2002). In their deep and comprehensive form, the EPA proposals and its negotiations have alienated some countries who feel unready for it. Despite the long-term benefits it proposes to offer, some regions and countries have hesitated to sign the EPAs because they believe that these EPAs would only serve EU's interest against theirs in the immediate to long-term period. 
Of course, the ACP regions and countries are partly to blame for the EPA negotiations albatross. They did not own the EPA negotiation process. It was and still is mainly driven by the EU (EurActiv 2013, Griffith et al. 2007, ACP Council of Ministers 2006). Did the ACP regions appear indifferent to the EPA negotiation sometime because they knew and preferred existing options of trading scheme? Yes, without a doubt, as for instance indicated by the letter written to the WTO special and differential treatment on regional trade agreements involving ACP countries (ACP Group of States 2004). Hence, although the EU seemed to have tried to downplay EPA options, perhaps a clear communication of preferences for the GSPs would have struck the right cord among the EU stakeholders. Nonetheless, on the basis of their individual and collective negotiation behaviours, it can be observed that sometimes they did not express their true state of feelings and perception with the EU. A typical case in point is when they consented to a joint review report about the negotiations in July 2007 when they still had disagreements about it (ACP Group of States and European Union 2007). This is not to say the ACP regions did not express their intentions to the EU at all. But why did they consent to a review report when they still had irreconcilable differences as there appear to be on the EPA? The ACP Group would need to be straightforward as much as possible in its trade and development relations with the EU.

Finally, the EU needs to determine the course of action to resolve the current impasse on EPA negotiations with ECOWAS and some other ACP RECs that have not signed regional EPA. How would the GSP/GSP+ and EBA schemes co-exist with the EPA regime in the same custom unions? This is crucial as the consequences of such scenario could be detrimental to the trade and development efforts of those regions, as have been argued by Vickers (2011) and Czapnik (2014). Specifically, for instance, what will happen if Ghana and Cote d'Ivoire remain the only countries to sign EPA in ECOWAS? How will that trade regime operate in the custom union? Any action or inaction on this issue would result in the worsening of the developmental progress made so far in some of these regions and will not be positive for EU's global image as a long-time friend to developing countries. Both EU and the ACP partners must avoid such scenario at all cost.

Received 9 March 2017, Revised 18 April 2017, Accepted 2 May 2017 


\section{References}

ACP-EC Council of Ministers. "ACP-EC Council of Ministers Resolution on Economic Partnership Agreements (EPAs) and Regional Integration" ACP-EC Council of Ministers Meeting, Addis Ababa, June 12-13, 2008.

ACP Council of Ministers. "Decisions and Resolutions of the 79th Session of the ACP Council of Ministers", Gaborone, Botswana, May 4-5, 2004.

. "Declaration of the 81st Session of the ACP Council of Ministers on the Economic Partnership Agreements (EPAs)." 81st Session of the ACP Council of Ministers, Brussels, June 21-22, 2005.

. "Decision $\mathrm{N}^{\circ}$ 2/Lxxxiii/06 of 83rd Session of the ACP Council of Ministers on the Economic Partnership Agreements (EPAs)" 83rd Session of the ACP Council of Ministers, Port Moresby, 2006.

. "Decision $\mathrm{N}^{\circ} 4 / \mathrm{LXXXV/07}$ of the 85th Session of the ACP Council of Ministers: Economic Partnership Agreements (EPAs)." Brussels The ACP Council of Ministers, $2007 \mathrm{a}$.

. "Declaration of the ACP Council of Ministers at its 86th Session Expressing Serious Concern on the Status of the Negotiations of the Economic Partnership Agreements." Brussels: ACP Council of Ministers, 2007b.

. "Resolution of the 99th Session of the ACP Council of Ministers - Economic Partnership Agreements." Nairobi, Kenya: ACP Secretariat, 2014.

ACP Group of States. "ACP Guidelines for the Negotiations of Economic Partnership Agreements." Brussels: ACP Group of States, 2002.

. "Submission on Regional Trade Agreements Paper by the ACP Group of States: Developmental Aspects of Regional Trade Agreements and Special and Differential Treatment in WTO Rules: Gatt 1994 Article Xxiv and the Enabling Clause." Geneva: WTO Secreatariat, 2004.

ACP Group of States, and Council of the EU. "Joint ACP-EU Declaration on the Review of the Economic Partnership Agreements (EPAs) Negotiations." Brussels: ACP Group of States \& Council of the EU, 2006. 
ACP Group of States, and European Community and its Member States. "Partnership Agreement Between the Members of the African, Caribbean and Pacific Group of States of the One Part, and the European Community and its Member States, of the Other Part." Cotonou: ACP Group of States \& European Community and its Member States, 2000.

ACP Group of States, and European Union. "ACP-EU Economic Partnership Agreement Negotiations Cotonou Agreement Article 37.4 Review." Brussels: ACP Group of States; European Union, 2007.

ACP Heads of State and Government. "Accra Declaration: Sections on Economic Partnership Agreement in the Accra Declaration." Sixth Summit of ACP Heads of State, Accra, October 2 - 3, 2008.

. Sipopo Declaration "The Future of the ACP Group in a Changing World: Challenges and Opportunities." 7th Summit of ACP Heads of State and Government, Sipopo, Equatorial Guinea, December 13-14, 2012.

African Union. "Proposal for a Common and Enhanced Trade Preference System for Least Developed Countries (LDCs) and Low Income Countries (LICs)." 7th regular session of the Conference of Trade Ministers from the African Union, Addis Ababa, December 2, 2011.

AU Conference of Ministers of Trade. "Nairobi Declaration on Economic Partnership Agreement." 4th Ordinary Session of African Union Conference of Ministers of Trade, Nairobi, Kenya, April 12-14, 2006.

. "Addis Ababa Ministerial Declaration on Economic Partnership Agreements Negotiations." Conference of Ministers of Trade of the African Union 3rd Extraordinary Session, Addis Ababa, Ethiopia, January 15-16, 2007.

AU Conference of Ministers of Trade and of Finance. "Addis Ababa Declaration on EPA Negotiations." AU Conference of Ministers of Trade and of Finance, Addis-Ababa - Ethiopia, April 1-3, 2008.

Avenhaus, Rudolf, and I.William Zartman, eds. Diplomacy Games Formal Models and International Negotiations. Heidelberg: Springer: Berlin, Heidelberg, \& New York, 2007.

Barfod, Mikael. "The CARIFORUM EPA-Stating The Facts "Barnacle-Grenada Newspaper and Business Journal, 13 August 2015, 2015. Accessed August 18, 2015. http./ 
www.barnaclegrenada.com/index.php/regional-news/3411-the-cariforum-epa--statingthe-facts.

Bassilekin, Achille. "Possibility of obtaining a new ACP-EC waiver at the WTO." ECDPM Discussion Paper DP-71 (2007).

Berthelot, Jacques "Why ECOWAS should not sign the EPA." ROPPA (Network of Peasant Organisations and Agricultural Producers of West Africa) Convention, Niamey, June 15-19, 2014.

Bilal, Sanoussi. "North-South Agreements: Integrating developing countries into the World Trading System?" WTO Secretariat Seminar - Regional Trade Agreements \& The WTO, WTO Secretariat, Geneva, November 14, 2003.

Bilal, Sanoussi, and Francesco Rampa. "Reviewing EPAs negotiations and alternative scenarios." Trade Negotiation Insight 5, 1 (2006a):1-3.

. "Alternative (to) EPAs: Possible scenarios for the future ACP trade relations with the EU." In ECDPM Policy Management Report. Maastricht: ECDPM, 2006b.

Bishop, Matthew Louis, Tony Heron, and Anthony Payne. "Caribbean development alternatives and the CARIFORUM-European Union Economic Partnership Agreement." Journal of International Relations and Development 16, 1 (2013):82-110. doi: 10.1057/ Jird.2012.5.

Borrmann, Axel, Harald Großmann, and Georg Koopmann. "The WTO Compatibility of the Economic Partnership Agreements between the EU and the ACP Countries." Intereconomics (2006). doi: 10.1007/s10272/006/0179/2.

Bouet, Antoine, David Laborde, and Simon Mavel. "Searching for an alternative to Economic Partnership Agreements." IFPRI Brief 48 (2007).

Bretherton, Charlotte, and John Vogler. The European Union as a Global Actor. London: Routledge. 1999.

. "The European Union as a Sustainable Development Actor: the Case of External Fisheries Policy." Journal of European Integration 30, 3 (2008):401-417. doi: 10.1080/0703633080 2142012.

Bruce, Emmanuel. "EPAs in limbo as Nigeria, others resist it" Graphic Online, March 1, 2016. Accessed March 1, http://www.graphic.com.gh/business/business-news/59336- 
epas-in-limbo-as-nigeria-others-resist-it.html.

Buzan, Barry. "From international system to international society: structural realism and regime theory meet the English school." International Organization 47, 03 (2009):327. doi: $10.1017 / \mathrm{s} 0020818300027983$.

CACID. "West Africa, European Union EPA negotiations Civil society Strongly Opposed to further opening West African market to the European Union." Darkar: Africa Centre for Trade, Integration and Development (ACTDP), 2013.

CARICOM Secretariat. "CARICOM Chairman stresses need for economic alternatives." Georgetown, Guyana: CARICOM Secretariat, 2006.

Civil Society Organisations against EPA. "Nairobi Statement on EPAs, November 2012." Nairobia, Kenya: NGOMA; Kenya Human Rights Commission, 2012.

CONCORD. "The EPA between the EU and West Africa: Who benefits? Coherence Of EU Policies For Development." Spotlight Report 2015, Policy Paper (2015).

Coomson, Joseph. "West Africa: Ecowas Urged to Pull Out of EPA Negotiations." The Chronicle, November 22, 2005.

Crump, Larry. "Negotiation Process and Negotiation Context." International Negotiation 16, 2 (2011):197-227. doi: 10.1163/138234011×573011.

. "A Temporal Model of Negotiation Linkage Dynamics." Negotiation Journal (2007). doi: 10.1111/j.1571-9979.2007.00133.x.

Czapnik, Ben "Côte d'Ivoire's EPA: Between a rock and a hard place." Bridges Africa 3, 5 (2014).

Delegation of the European Commission in Ghana. "Ghana and EU Initial Interim Economic Partnership Agreement." Accra: EU Delegation to Ghana, 2007.

Delegation of the European Union to Ghana. "EU Welcomes Signature and Ratification of Stepping Stone Economic Partnership Agreement." Accra: European External Action Service-Delegation of the European Union to Ghana, 2016.

Diarra, Soumaila "West Africa Farmers Against EU Economics, International Competition." AFK Insider, January 20, 2015. Accessed January 21, 2015. http://afkinsider.com/85554/ west-african-farmers-against-eu-economics-international/2/\#sthash.oXeVGDPR.dpuf. 
Dür, Andreas, and Manfred Elsig. "Principals, agents, and the European Union's foreign economic policies." Journal of European Public Policy 18, 3 (2011):323-338.

ECDPM. "EPAs: There is no Plan B-An interview with Peter Mandelson." Trade Negotiation Insight 6, 5(2007):1-3.

Economic Justice Network. "Civil society organisations condemn approval of EPAs by ECOWAS Leaders." Accra: Economic Justice Network, 2014.

Economic Justice Network of Ghana. "Minister urged to take up new alternative to Interim EPAs." Africa Trade Agenda 4, 1 (2012).

ECOWAS Ministerial Monitoring Committee. "Economic Partnership Agreement Negotiations Between West Africa And The European Union: Status Of The Negotiations On The Text Of The Agreement And The Protocol on EPADP." Ministerial Monitoring Committee on the EPA Negotiations, Accra November 28 - 30, 2011.

ECOWAS Ministers of Trade. "West African Trade Ministers Meet on Negotiations With EU." Accra: ECOWAS Commission, 2011.

ECOWAS Ministers of Trade and Finance. "Ministers Meeting on EPAs Calls For Additional Resources." Accra: ECOWAS Commission, 2003.

Editor. "East Africa: Sign the Economic Partnership Agreement" The Daily Monitor, February 7, 2017. Accessed March 10, 2017. http:/www.monitor.co.ug/OpEd/Editorial/ 689360-3803948-10t7gyz/index.html.

EurActiv. "EU pressures seven African countries to complete trade agreements." EurActiv, April 23, 2013. Accessed June 13, 2016. http://www.euractiv.com/section/ development-policy/news/eu-pressures-seven-african-countries-to-complete-tradeagreements/.

European Commission. "EU Mandate for Trade Negotiations with African, Caribbean and Pacific Countries." Brussels: European Commission, 2002a.

. "Recommendation for a Council Decision authorising the Commission to negotiate Economic Partnership Agreements with the ACP countries and regions (presented by the Commission)." Brussels: European Commission, 2002 b.

. "Communication from the Commission to the Council, the European Parliament and the European Economic and Social Committee of July 7, 2004: "Developing countries, 
international trade and sustainable development: the function of the Community's generalised system of preferences (GSP) for the ten-year period from 2006 to 2015." Official Journal of the European Communities C 242 (2004).

. "Commission Staff Working Document: The Trade and Development Aspects of EPA Negotiations." Brussels: European Commission, 2005a.

. "GSP: The new EU preferential terms of trade for developing countries The EU Generalised System of Preferences." Brussels: European Commission, 2005b.

. "The CARIFORUM-EC Economic Partnership Agreement." edited by DG Trade. Brussels: European Commission, 2008a.

. "Six common misconceptions about Economic Partnership Agreements (EPAs)" edited by DG Trade. Brussels, $2008 \mathrm{~b}$.

. "Everything But Arms (EBA) - Who benefits?". Brussels, 2013.

. "The EU's Generalised Scheme of Preferences (GSP)." Brussels: European Commission, 2014a.

. "European Union, Trade in goods with Nigeria." European CommissionEurostat, 2014b.

. "State of Play of EPA negotiations: Updated February 2016." Brussels: European Commision, 2016.

. "European Union, Trade in goods with Cape Verde." edited by DG Trade. Brussels: European Commission, 2017a.

. "Overview of Economic Partnership Agreements-Updated January 2017." edited by DG Trade. Brussels: European Commision, $2017 \mathrm{~b}$.

. "Overview of Economic Partnership Agreements-Updated April 2017." edited by DG Trade. Brussels: European Commission, 2017c.

Faber, Gerrit J., and Jan Orbie. European Union trade politics and development : 'Everything but Arms' unravelled, Routledge studies in Development Economics. London: Routledge. 2007.

Faber, Gerrit, and Jan Orbie. "Everything But Arms: Much More than Appears at First Sight." JCMS 47, 4 (2009):767-787. 
Fellowship of Christian Councils and Churches in West Africa. "ECOWAS-EU Economic Partnership Agreement "What did not happen in 10 years should not happen under pressure!" FECCIWA LOBBY ENGAGEMENTS: Abuja, Accra, Lomé, Berlin, Brussels." Lome, Togo: Fellowship of Christian Councils and Churches in West Africa (FECCIWA) EPA info Brief, 2014.

Fisher, Roger, and William Ury. Getting to Yes: Negotiating Agreement without Giving In. London: Hutchinson Business. 1981.

Flint, Adrian. Trade, poverty and the environment : the EU, Cotonou and the AfricanCaribbean-Pacific bloc. Basingstoke (England): Palgrave Macmillan. 2008.

Fontagné, Lionel, David Laborde, and Cristina Mitaritonna. "An Impact Study of the EU-ACP Economic Partnership Agreement (EPAs) in the Six ACP Regions." CEPII Working Paper No 2008 - 04 (2008a).

. "An Impact Study of the EU-ACP Economic Partnership Agreements (EPAs) in the Six ACP Regions - Final Report." Paris: Commission of the European UnionDirectorate General for Trade, $2008 \mathrm{~b}$.

Frederiksen, Jonas, and Sanoussi Bilal. "Funding Propsects for EPAs: The Mid-Term Reviews and Availability of Resources." Trade Negotiation Insight 3, 4 (2004):4-5.

Galtung, Johan. "A Structural Theory of Aggression." Journal of Peace Research 1, 2 (1964):95-119. . "Structural Theory of Imperialism." Journal of Peace Research 8, 2 (1971):81117.

Gasiorek, Michael, Javier Lopez Gonzalez, Peter Holmes, Maximiliano Mendez Parra, Jim Rollo, ZhenKun Wang, Maryla Maliszewska, Wojciech Paczynski, Xavier Cirera, Dirk Willenbockel, Sherman Robinson, Kamala Dawar, Francesca Foliano, and Marcello Olarreaga. "Mid-term Evaluation of the EU's Generalised System of Preferences: Final Report." European Commission, 2010.

Ghana Trade Union Congress, Ghana Trade and Livelihoods Coalition, General Agricultural Workers Union, and Third World Network - Africa. "Civil Society Urges Trade and Industry Minister, Ms. Hannah Tetteh, to Push For Solidarity Fund in the EPA Process." Accra: TWN-Africa, 2012. 
Girvan, Norman. "Towards a Single Development Vision and the Role of a Single Market " The Twenty-Eighth Meeting of the Conference of Heads of Government of the Caribbean Community (CARICOM), Needham's Point, Babardos, July 1-4, 2007.

Glaser, Charles L. "Structural Realism in a more complex world." Review of International Studies 29, 3 (2003):403- 414. doi: 10.1017/s0260210503004030.

Global CSOs against EPA. "Enough is Enough! Time to Abandon the E.P.A. Charade!! (Statement of Global EPA Strategy Meeting, Harare)." Harare, Zimbabwe: Global Civil Society Organisations against Economic Partnership Agreements, 2013.

Gonzales, Anthony Peter. "CARIFORUM'S decision to sign the EPA." Trade Negotiation Insight 7, 8 (2008):2-3.

Griffith, Mari, Sophie Powell, Matt Griffith, Tim Rice, Tzvetelina Arsova, Paul Cook, Mike Gidney, and Paul Goodison. "Partnership under pressure: an assessment of the European Commission's conduct in the EPA negotiations." 2007.

Guzzini, Stefano. "Structural Power: the Limits of Neorealist Power Analysis." International Organization 47, 3 (1993).

Heron, Tony. "Asymmetric bargaining and development trade-offs in the CARIFORUMEuropean Union Economic Partnership Agreement." Review of International Political Economy 18, 3 (2011):328-357. doi: Doi 10.1080/09692290.2010.481916.

Herz, Bernhard, and Marco Wagner. "The Dark Side of the Generalized System of Preferences." Working Paper 02/2010(2010).

Hills, Jill. "Dependency theory and its relevance today: international institutions in telecommunications and structural power." Review of International Studies 20 (1994): 169-186.

IMANI Ghana. "IMANI Report: Evidence-based support for Ghana to ratify the EPA" Myjoyonline.com April 14, 2014, 2014. Accessed April 15, 2014. http://www.myjoyonline. com/business/2014/April-14th/imani-report-evidence-based-support-for-ghana-to-ratifythe-epa.php.

Karingi, Stephen, Rémi Lang, Nassim Oulmane, Romain Perez, Mustapha Sadni, and Hakim Ben Hammouda. "Economic and Welfare Impacts of the EU-Africa Economic Partnership Agreements." In ATPC Work in Progress UN Economic Commission for 
Africa, 2005.

Keohane, Robert O. "Theory of World Politics: Structural Realism and Beyond." In Neorealism and Its Critics, edited by Robert O. Keohane, 159-203. New York: Columbia University Press, 1986.

Kwa, Aileen, Peter Lunenborg, and Wase Musonge. "African, Caribbean and Pacific (ACP) countries' position on Economic Partnership Agreements (EPAs)." edited by Directorate-General For External Policies of the Union Directorate B European Parliament, Policy Department. Brussels: European Parliament, 2014.

Larsén, Magdalena Frennhoff. "Principal-Agent Analysis with One Agent and Two Principals: European Union Trade Negotiations with South Africa." Politics \& Policy 35, 3 (2007a):440-463.

. "Role of Commission in third party negotiation-one agent two sets of principals." Biennial Conference of the European Union Studies Association, Montréal, May 17-19, $2007 \mathrm{~b}$.

. "Trade Negotiations between the EU and South Africa: A Three-Level Game." Journal of Common Market Studies 45, 4 (2007c):857-881.

Lax, David A. "Optimal Search in Negotiation Analysis." Journal of Conflict Resolution 29, 3(1985):456-472. doi: 10.1177/0022002785029003004.

Lax, David A., and James K. Sebenius. "Negotiating through an Agent." The Journal of Conflict Resolution 35, 3 (1991):474-493.

Lodge, Junior. "Challenges Facing the Caribbean During EPA Negotiations." Trade Negotiation Insight 1, 3 (2002):3-6.

Mearsheimer, John J. "Structural Realism." In International Relations Theories, Discipline and Diversity, edited by Tim Dunne, Milja Kurki and Steve Smith, 71-88. Oxford: Oxford University Press, 2006.

Meunier, Sophie. "What Single Voice? European Institutions and EU-U.S. Trade Negotiations." International Organization 54, 1 (2000):103-135.

. Trading voices : the European Union in international commercial negotiation. Princeton, N.J. ; Oxford: Princeton University Press. 2005. . "Managing Globalization? The EU in International Trade Negotiations." 
Journal of Common Market Studies 45, 4 (2007):905-926.

Meunier, Sophie, and Kalypso Nicolaidis. "The European Union as a conflicted trade power." Journal of European Public Policy 13, 6 (2006):906-925. doi: 10.1080/1350176 0600838623.

. "The European Union as a Trade Power." In The International Relations of the European Union, edited by Christopher Hill and Michael Smith. Oxford: Oxford University Press, 2005.

Myjoyonline.com. "Don't sacrifice local economies for EU's aid; Economic Justice Network (EJN), cautions ECOWAS countries." Myjoyonline.com, February 5, 2014. Accessed February 5, 2014. http.xwww.myjoyonline.com/business/2014/February-5th/ dont-sacrifice-manufacturing-for-europes-promised-aid-ejn-cautions-ecowas-countries. php.

Narlikar, Amrita , and John S. Odell. "The strict distributive strategy for a bargaining coalition: the Like Minded Group in the World Trade Organization, 1998-2001." In Negotiating Trade Developing Countries in the WTO and NAFTA, edited by John S. Odell. Cambridge University Press, 2006.

Nicolaidis, Kalypso "Minimizing agency costs in two-level games: lessons from the trade authority controversies in the United States and the European Union." In Negotiating on Behalf of Others: Advice to Lawyers, Business Executives, Sports Agents, Diplomats, Politicians, and Everybody Else, edited by Robert H. Mnookin and E. Lawrence Susskind, 87-126. Thousand Oaks, CA: Sage Publications, 1999.

Odell, John S. "Creating Data on International Negotiation Strategies, Alternatives and Outcomes." International Negotiation 7, 1 (2002):39-52. doi: 10.1163/15718060 2401262410.

. "Breaking Deadlocks in International Institutional Negotiations: The WTO, Seattle and Doha." International Studies Quarterly (2009):1-47.

. "Three Islands Of Knowledge About Negotiation In International Organizations." Journal of European Public Policy 17, 5 (2010):619-632. doi: 10.1080/ 13501761003748534.

ODI, and ECDPM. "Interim EPAs in Africa: What's in them? And what's next?" Trade Negotiation Insight 7, 3 (2008). 
Overseas Development Institute. "The Costs to the ACP of Exporting to the EU under the GSP Final Report." London, United Kingdom: Overseas Development Institute 2007.

Permanet Delegation of the European Commission to the WTO. "Communication from the European Community and its Member States (to WTO): Concept Paper on NonDiscrimination" edited by European Commission. Geneva: WTO Working Group on the Relationship between Trade and Investment, 2002.

Pollack, Mark A. "The Commission as an Agent: Delegation of Executive Power in the European Union." In The Engines of European Integration: Delegation, Agency, and Agenda Setting in the EU. Oxford: Oxford University Press, 2003a.

. The Engines of European Integration: Delegation, Agency, and Agenda Setting in the EU. Oxford: Oxford University Press. 2003b.

PON Staff. "BATNA and Other Sources of Power at the Negotiation Table." PONProgram on Negotiation at Harvard Law School

Raihan, Selim, Mohammad A. Razzaque, and Edwin Laurent. "Economic Partnership Agreements: Assessing Potential Implications from Some Alternative Scenarios." 2007.

Sebenius, James K. Negotiating the Law of the Sea: Lessons in the Art and Science of Reaching Agreement, Harvard Economic Studies. Harvard Harvard University Press. 1984.

38, 1(1992):18-38.

. "Negotiation Analysis: A Characterization and Review." Management Science . "Negotiation Analysis: Between Decisions and Games" In Advances in Decision Analysis, edited by Edwards Ward, Miles Ralph and von Winterfeldt Detlof. Cambridge: Cambridge University Press, 2006.

. "Negotiation Analysis: From Games to Inferences to Decisions to Deals." Negotiation Journal (2009):449-465.

South Centre. "Revisiting EPAs and WTO Compatibility." South Centre Analytical Note (2005).

. "The Cotonou Partnership Agreement, The Economic Partnership Agreements and WTO Compatibility: Can Initialed Interim EPAs be Notified?" Analytical Note 
(2009).

Spangler, Brad, ed. Best Alternative to a Negotiated Agreement (BATNA). Edited by Guy Burgess and Heidi Burgess, Beyond Intractability. Boulder: Conflict Information Consortium, University of Colorado, 2012.

Stevens, Christopher, Mareike Meyn, and Jane Kennan. "Comparative Analysis of Liberalisation Schedules and other Commitments of the African interim EPAs." ECDPM Workshop, Brusssels, April 17, 2008.

Third World Network - Africa. "The case against the EPAs." Africa Trade Agenda 2, 1 (2005a).

. "Europe-Africa Free Trade Agreements 'Stop EPAs' campaign gains momentum." African Trade Agenda 2, 1 (2005b).

. "Ghana-EU Interim Economic Partnership Agreement: Problems And Challenges." In Policy Brief, edited by Tetteh Hormeku. Accra: Third World NetworkAfrica, 2009.

. "Press Communique from the West Africa Civil Society on the Economic Partnership Agreement." Dakar, Abuja: Third World Network-Africa, 2013.

UNECA. "Developments in International Trade and WTO/EPA Negotiations." Addis Ababa, Ethiopia, Fifth Session of the Committee on Trade, Regional Cooperation and Integration, October 8-10, 2007.

Vickers, Brendan. "Between a Rock and a Hard Place: Small States in the EU-SADC EPA Negotiations." The Round Table 100, 413 (2011):183-197. doi: 10.1080/00358533. 2011.565631 .

Wallie, Roux. "An 'Alternative' to the EPA Proposals: A Provision Dropped from the EU's 'EPA Negotiating Manual'?" Paper presented at the Tralac Annual Conference, Cape Town, South Africa, October 13-14, 2005.

Waltz, Kenneth N. "Structural Realism after the Cold War." International Security 25, 1 (2000):5-41.

West African Civil Society Institute. "West African Civil Society Declaration on the Economic Partnership Agreements and Common External Tariff ": West African Civil Society 2013. 
West African Civil Society Platform. "West African CSOs strongly warn ECOWAS Negotiators ahead of EPA Meeting." Accra: West Africa Civil Society Platform (POSCAO), 2013.

West African Civil Society Platform on Cotonou Agreement. "West African Civil society strongly oppose further opening of West African market to the EU." Citifmonline.com, February 19, 2013.

Wheeler, Michael. "Negotiation Analysis; An Introduction." Harvard Business School Review 9-801-156 (2002).

Williams, Yentyl. "Shifting Between Hegemony and Dominance? A Neo-Gramscian Analysis of the EU as a Structural Foreign Policy Actor: The Singular Case of the Cariforum-EU Economic Partnership Agreement." Bruges Regional Integration \& Global Governance Papers 1/2004 (2014).

WTO Ministerial Conference. "European Communities-The ACP-EC Partnership Agreement, Decision of 14 November 2001." WTO Ministerial Conference, Fourth Session, Doha, November 9-14, 2001.

WTO Negotiating Group on Rules. "Second Submission on Regional Trade Agreements by the European Communities." edited by Delegation of the European Communities to the WTO. Geneva: WTO, Negotiating Group on Rules, 2005.

Zartman, I. William. "Comparative Case Studies." International Negotiation 10, (2005):315 . 